\title{
Origine du mobilier céramique du Bronze ancien et moyen de la sphère des Pyrénées nord occidentales
}

Patrice Dumontier et Fabien Convertini

\section{Q OpenEdition}

\section{Journals}

Édition électronique

URL : http://journals.openedition.org/adlfi/7619

ISSN : 2114-0502

Éditeur

Ministère de la culture

Référence électronique

Patrice Dumontier et Fabien Convertini, « Origine du mobilier céramique du Bronze ancien et moyen de la sphère des Pyrénées nord occidentales », ADLFI. Archéologie de la France - Informations [En ligne], Aquitaine, mis en ligne le 01 mars 2007, consulté le 30 avril 2019. URL : http:// journals.openedition.org/adlfi/7619

Ce document a été généré automatiquement le 30 avril 2019

(c) Ministère de la Culture et de la Communication, CNRS 


\title{
Origine du mobilier céramique du Bronze ancien et moyen de la sphère des Pyrénées nord occidentales
}

\author{
Patrice Dumontier et Fabien Convertini
}

Identifiant de l'opération archéologique : 025101

Date de l'opération : 2007 (PC)

\section{Historique du projet}

1 L'Âge du Bronze a fait l'objet d'un nombre important d'études et des synthèses ont été proposées à l'échelle régionale pour le sud-ouest de la France (Guilaine,1972, 1976 ; J. Roussot-Larroque, 1989,1996) ou plus limitée sur le plan géographique ou chronologique (Martin, 1989; Gardes, 1993 ; Blanc, 1987, 2001 ; Marembert, 2000, par exemple). Dans les Pyrénées nord-occidentales, à partir d'une documentation importante mais souvent ancienne et dominée par les sites sépulcraux, un modèle d'occupation du territoire a été proposé autour d'un pastoralisme transhumant. Cependant, si le pastoralisme est bien démontré qu'en est-il du territoire de la communauté connue à travers ses biens matériels et notamment par la céramique?

2 Cette céramique montre une production pyrénéenne spécifique, bien individualisée pour certaines phases du Bronze ancien, mais dans lesquelles des influences méditerranéennes (poladiennes) et médocaines sont sensibles sur certains secteurs géographiques nord et est. 
Des fouilles récentes bien documentées associées à des séries de datations ${ }^{14} \mathrm{C}$ permettent de renouveler l'analyse typo-chronologique. Afin d'aborder la notion de circulation des biens et des hommes ainsi que celle de "territoire" au sens large, nous nous proposons de réaliser une série d'analyses pétrographiques des pâtes afin de rechercher la provenance des argiles utilisées et d'observer de façon plus approfondie les techniques de fabrication. Notre objectif est double:il s'agit de préciser la typo-chronologie et notamment d'observer les évolutions des phases de transition (Néolithique final - Bronze ancien et Bronze ancien-Bronze moyen), mais aussi, en recherchant les zones de production, de réfléchir à la notion de territoire parcouru (nomadisme) ou de terroirs occupés de façon permanente.

Ce projet réunit sept chercheurs sur une aire géographique qui correspond aux PyrénéesAtlantiques (le Béarn), aux Hautes-Pyrénées et aux Landes. Nous avons prévu de réaliser, sur trois années, 150 analyses pétrographiques qui viendront compléter celles des céramiques d'Apons (13 analyses), Droundak (18 analyses) et l'Homme de Pouey (7 analyses) qui ont constitué la base de ce projet.

\section{Premiers éléments de synthèse et perspectives}

5 Dans les vallées pyrénéennes et en moyenne montagne, les analyses réalisées à partir du mobilier des grottes sépulcrales d'Apons, de Droundak et de l'Homme de Pouey apportent des premières réponses aux questions posées, complétées par les sites des Landes (50 analyses) aux spectres différents (une partie de mobilier provient de sites campaniformes et d'habitats). Sur l'ensemble des analyses, le mobilier céramique est très majoritairement confectionné avec des argiles provenant de gîtes proches du site archéologique de découverte. Cependant, des vases à provenances plus éloignées nous renseignent sur certains déplacements en vallée (provenance sud et nord pour la grotte d'Apons) et en montagne (vallée du Barétous à deux jours de marche pour l'un des vases de Droundak). Certains vases de cette cavité sépulcrale correspondraien donc à des vases usagés issus d'habitat et non pas à une production spécifique. Dans la limite des analyses effectuées pour le département des Landes, il y a continuité dans les processus techniques entre la céramique campaniforme et la celle du Bronze ancien et moyen. Sauf exception il n'y a pas de distinction entre les argiles et inclusions utilisées et les vases de différentes morphologies.

6 Enfin, et pour faire le lien avec les travaux déjà menés sur la céramique de sites d'altitude des Pyrénées-Atlantiques ayant initié le PCR, les vases sépulcraux du Bronze ancienmoyen renferment tous de la chamotte, comme ceux des sites d'habitat des Landes. Dans les autres séries de la sphère des Pyrénées nord-occidentales, le futur travail du PCR devra donc se fixer parmi les buts à atteindre la mise en évidence de manipulations de particules et les pratiques culturelles au Bronze ancien et moyen.

\section{Perspectives}

7 Cette première année démontre l'intérêt d'un travail réalisé sur une population statistique significative. Les objectifs du PCR nécessitent de poursuivre l'analyse en intégrant plusieurs séries représentatives. Il s'agit notamment de prendre en compte la documentation provenant des fouilles des tumulus du Pont-Long et d'ajouter à cette série 
funéraire le mobilier découvert en contexte d'habitats. Un travail de prospection des gîtes avec analyse pétrographique des argiles sera également à réaliser.

\section{INDEX}

operation Projet collectif de recherche (PCR)

Index chronologique : âge du Bronze

Thèmes : analyse des données chronologiques, analyse des matériaux, analyse documentaire, argile, céramique campaniforme, céramique du bronze, documentation, grotte sépulcrale, nomadisme, pastoralisme, pétrographie, radiocarbone, technologie de l'argile, transhumance, tumulus

Index géographique : Aquitaine, Pyrénées-Atlantiques (64)

\section{AUTEURS}

PATRICE DUMONTIER

BEN 